\title{
PENGARUH NAUNGAN DAN PEMUPUKAN NITROGEN TERHADAP KARAKTERISTIK MORFOLOGIS RUMPUT GAJAH DWARF (Pennisetum purpureum cv Mott)
}

\author{
Charel Rily Rellam, S. Anis*, A. Rumambi, Rustandi
}

Fakultas Peternakan Universitas Sam Ratulangi, Manado 95115

\begin{abstract}
ABSTRAK
Penelitian ini bertujuan untuk mengetahui sampai sejauh mana respons tanaman ini terhadap interaksi perlakuan naungan dan tingkat pemupukan nitrogen. Perlakuan yang diuji dalam penelitian ini terdiri dari level pupuk $\mathrm{N} ; \mathrm{P}_{1}=$ tanpa pemupukan; $\mathrm{P}_{2}=$ pemupukan sebanyak $200 \mathrm{~kg}$ Urea/ha; $\mathrm{P}_{3}=$ pemupukan sebanyak $400 \mathrm{~kg}$ Urea/ha; $\mathrm{P}_{4}=$ pemupukan sebanyak $800 \mathrm{~kg}$ Urea/ha. Level naungan $\mathrm{N}_{1}=0 \%$ (tanpa naungan) dan $\mathrm{N}_{2}=70 \%$ naungan. Variabel yang diukur dalam penelitian ini panjang daun, jumlah daun dewasa, dan tinggi tanaman. Hasil analisis statistik menunjukkan bahwa untuk mencapai panjang daun yang maksimal pada kondisi lingkungan ternaung dibutuhkan dosis pemupukan 200 $\mathrm{kg}$ urea/ha, sedangkan pada lingkungan tanpa naungan membutuhkan $800 \mathrm{~kg}$ urea/ha. Pada lingkungan terbuka tanpa naungan jelas daun maksimal dicapai pada pemupukan nitrogen $800 \mathrm{~kg}$ urea/ha, sedangkan pada lingkungan ternaung untuk mencapai jumlah daun tersebut belum membutuhkan pupuk nitrogen. Selanjutnya tanaman tertinggi dicapai pada level pemupukan $400 \mathrm{~kg}$ urea/ha pada perlakuan tanpa naungan, sedangkan pada lingkungan ternaung untuk mencapai tinggi tersebut belum membutuhkan pupuk nitrogen. Berdasarkan hasil penelitian ini dapat disimpulkan bahwa: 1. Naungan berkontribusi positif dalam penyediaan unsur hara nitrogen untuk kebutuhan tanaman rumput P.purpureum cv. Mott. 2.
\end{abstract}

\footnotetext{
*Korespondensi (corresponding Author)

Email: selvie_anis@yahoo.com
}

Pada lingkungan tanpa naungan kebutuhan pupuk nitrogen lebih banyak untuk menghasilkan panjang daun, jumlah daun dan tinggi tanaman di bandingkan pada kondisi ternaung.

Kata kunci : Pemupukan, Naungan, Rumput Gajah dwarf, Morfologis, Karakteristik.

ABSTRACT
THE EFFECT OF SHADING
AND NITROGEN FERTILIZATION
MORPHOLOGICAL
ON
CHARACTERISTICS OF DWARF
ELEPHANT GRASS (Pennisetum
purpureum cv. mott). This study was
conducted to determine the responses of
Dwarf Elephant grass (P. purpureum cv.
Mott.) fertilized with different nitrogen
levels and at different shading areas. A
Completely Randomized Design (CRD) in
a Factorial arrangement with 2 factors of
nitrogen levels and shading areas arranged
as follows: factor A = fertilization levels
of P1 = without fertilization (0\%); P2 =
200 kg urea/ha; P3 = 400 kg urea/ha; and
P4 = 800 kg urea/ha; whereas factor B =
shasing areas of N1 = no shading area
(0\%), and N2 = 70\% shading area.
Variables measured were including leaf
length, number of mature leaves, and plant
height. Research results showed that plants
needed about $200 \mathrm{~kg}$ urea/ha in order to
achieve maximum leaf length in shaded
area; whereas plants within no shading


area needed about $800 \mathrm{~kg}$ urea/ha to achieve maximum leaf length. To achieve maximum number of mature leaves in open area without shading plants needed about $800 \mathrm{~kg}$ urea/ha, and no need for nitrogen fertilization in shading area for plants to achieve such a maximum number of mature leaves. The highest plant height was achieved at the level of $400 \mathrm{~kg}$ urea/ha fertilization at open area (no shading), and there was no need of nitrogen fertilization for plants in shaded area in order to achieve their maximum height. It can be concluded that shading positively contributed to the availability of nitrogen to be used by Dwarf Elephant grass ( $P$. purpureum cv. Mott.). In open area without shading, plants need more nitrogen in the form of urea to produce leaf length, number of mature leaves, and plant height compared to shaded area.

Keywords: Fertilization, Shading, Elephant Grass, Plant morphology.

\section{PENDAHULUAN}

Ketersediaan pakan khususnya pakan hijauan baik kualitas, kuantitas maupun kontinuitasnya merupakan faktor yang penting dalam menentukan keberhasilan usaha peternakan ternak ruminansia. Hal ini disebabkan hampir 90\% pakan ternak ruminansia berasal dari hijauan dengan konsumsi segar perhari 10 - $15 \%$ dari berat badan, sedangkan sisanya adalah konsentrat dan pakan tambahan (Abdullah, 2012).

\section{Di Indonesia terkait dengan} masalah pangan pemerintah berupaya mencapai kedaulatan pangan, karena berbagai bahan pangan termasuk daging masih bergantung pada impor. Dilaksanakannya impor karena dianggap masih lebih murah dibandingkan dengan melakukan penggemukan sapi dalam negeri dengan memberi konsentrat yang harganya lebih mahal dan bersaing dengan kebutuhan pangan bahkan energi dan biofuel sedangkan di Australia pemeliharaan ternak mengandalkan padang rumput (Abdullah, 2012).

Kendala dalam penyediaan hijauaan pakan yang berkualitas dan berkelanjutan adalah lahan yang subur atau produktif, dimana penggunaan lahan produktif biasanya digunakan untuk tanaman yang bernilai ekonomis tinggi. Mengatasi masalah keterbatasan lahan tersebut dengan pemanfaatan lahan yang terintegrasi dengan tanaman individu seperti kelapa (Anis et al., 2015), atau dengan pemanfaatan lahan-lahan marjinal atau kurang produktif dengan pemberian unsur hara yang diperlukan tanaman dengan cara pemupukan yang sesuai dengan kebutuhan tanaman (Finindi et al., 2005).

Sajimin et al. (2001) menyatakan bahwa untuk memperoleh produksi yang tinggi pada lahan yang tingkat kesuburannya rendah dapat dilakukan dengan pemupukan. Penambahan unsur hara terutama Nitrogen $(\mathrm{N})$, Fospor $(\mathrm{P})$, 
dan Kalium (K) dalam tanah secara optimal pada tanaman dapat meningkatkan pertumbuhan dan produksi tanaman.

Tanaman dalam kondisi lingkungan ternaung jumlah radiasi matahari terbatas dan mempengaruhi secara negatif terhadap kapasitas fotosintesis, demikian juga akan berpengaruh terhadap respirasi, transpirasi, sintesis protein, produksi hormon, translokasi asimilat dan penuaan (Bona dan Monteiro, 2010).

P.purpureum cv. Mott memiliki kemampuan menghasilkan biomasa dan kualitas nutrisi tinggi, terlihat pada kandungan protein antara 10-15\% tergantung umur panen, bersifat perennial, produksi biomasa dan kualitas nutrisinya tinggi serta kandungan serat yang relatif rendah dan mengandung karbohidrat mudah tercerna (Urribari et al., 2005).

\section{MATERI DAN METODE PENELITIAN}

\section{Waktu dan Tempat Penelitian}

Pelaksanan penelitian dimulai bulan Februari sampai dengan bulan Mei 2016 bertempat di kebun percobaan milik Badan Penelitian dan Pembangunan Pertanian/Balai Pengkajian Teknologi Pertanian Sulawesi Utara (BPTP) Kebun Percobaan Pandu di Desa Talawaan
Bantik, Kecamatan Wori, Kabupaten Minahasa Utara, Provinsi Sulawesi Utara.

\section{Bahan dan alat}

Anakan rumput gajah Dwarf (Pennisetum purpureun cv. Mott), pupuk urea, Insektisida, herbisida, alat tulis (buku, pensil, bol point, spidol, dan mistar), gunting, pisau, parang, cangkul, spray, timbangan dijital, para-net, tali, pengukur suhu (Max-Min).

\section{Metode Penelitian}

Perlakuan yang diuji dalam penelitian ini terdiri dari level naungan dan level pemupukan sebagai berikut:

$\mathrm{N}_{1}=0 \%$ (tanpa naungan) dan $\mathrm{N}_{2}=70 \%$ naungan

$$
\begin{aligned}
\mathrm{P}_{1}= & \text { Tanpa Pemupukan } \\
\mathrm{P}_{2}= & \text { Pemupukan } 200 \mathrm{~kg} \mathrm{Urea/ha} \\
& \text { (kandungan } 92 \% \text { nitrogen). } \\
\mathrm{P}_{3}= & \text { Pemupukan } 400 \mathrm{~kg} \mathrm{Urea/ha} \\
& \text { (kandungan } 184 \% \text { nitrogen). } \\
\mathrm{P}_{4}= & \text { Pemupukan } 800 \mathrm{~kg} \text { Urea/ha } \\
& \text { (kandungan } 368 \% \text { nitrogen). }
\end{aligned}
$$

\section{Variabel Penelitian}

Variabel yang di ukur dalam penelitian ini adalah :

1. Panjang daun

2. Jumlah daun dewasa

3. Tinggi tanaman

\section{Rancangan Penelitian}


Perlakuan diatur secara faktorial 2 x 4 dengan rancangan dasar acak kelompok (RAK). Dengan demikian terdapat 8 kombinasi perlakuan yang diacak pada 3 kelompok sehingga terdapat 24 angka pengamatan. Analisis of Varians (ANOVA) digunakan untuk melihat ada tidaknya pengaruh perlakuan trhadap variabel yang diukur. Adanya perbedaan percobaan diuji lanjut dengan Tukey Simultan test dengan program mini tap versi 11 (Gomez dan Gomez,1995).

\section{HASIL DAN PEMBAHASAN}

Analisis statistik menunjukkan interaksi naungan dengan level pupuk nitrogen berpengaruh nyata $(\mathrm{P}<0,05)$ terhadap variabel panjang daun, jumlah daun dan tinggi tanaman yang diukur (Tabel 1).

\section{Panjang Daun}

Uji lanjut dengan Tukey Simultaneous test menunjukkan interaksi antara perlakuan lingkungan ternaung $70 \%$ dengan perlakuan level pupuk nitrogen $\mathrm{P} 2$, P3 dan P4 menghasilkan panjang daun masing-masing berturut-turut 52,66; 63,00 dan $54,70 \mathrm{~cm}$ berbeda nyata $(\mathrm{P}<0.05)$ lebih panjang dibandingkan dengan yang berinteraksi dengan perlakuan tanpa pemupukan nitrogen (P1) hanya mencapai panjang daun 49,33 $\mathrm{cm}$. Data panjang daun pada Tabel 1, menunjukkan bahwa untuk mencapai panjang daun maksimal pada lingkungan $0 \%$ naungan membutuhkan pupuk nitrogen dalam bentuk urea $800 \mathrm{~kg} / \mathrm{ha}$ sedangkan pada lingkungan $70 \%$ naungan untuk mencapai panjang daun yang setara dibutuhkan hanya $200 \mathrm{~kg}$ urea/ha.

Selanjutnya dari uji Tukey menunjukkan bahwa level pemupukan nitrogen pada lingkungan $0 \%$ naungan (100\% cahaya) daun terpanjang diperoleh pada interaksi perlakuan N1P4 dengan nilai $53,33 \mathrm{~cm}$ nyata $(\mathrm{P}<0,05)$ lebih panjang dari pada interaksi lainnya.

\section{Jumlah daun}

Hasil uji lanjut Tukey Test menunjukkan jumlah daun terbanyak diperoleh pada interaksi antara perlakuan naungan $70 \%$ dengan perlakuan semua level pupuk nitrogen P2, P3 dan P4. Sedangkan interaksi pada lingkungan $0 \%$ naungan dengan level pupuk nitrogen dalam bentuk urea $800 \mathrm{~kg} / \mathrm{ha}$ menghasilkan jumlah daun terbanyak dan berbeda nyata $(\mathrm{P}<0.05)$ lebih banyak dibanding dengan level pupuk nitrogen lainya. Data pada Tabel 1, menunjukkan bahwa untuk memperoleh hasil jumlah daun yang maksimal pada lingkungan $0 \%$ naungan diperlukan pemupukan nitrogen dalam bentuk urea $800 \mathrm{~kg} / \mathrm{ha}$, sedangkan 
Tabel 1. Interaksi perlakuan terhadap panjang daun, jumlah daun dan tinggi tanaman rumput P.purpureum cv Mott

\begin{tabular}{llll}
\hline Interaksi & Panjang Daun & Jumlah Daun & Tinggi Tanaman \\
\hline N1P1 & $46,66^{\mathrm{b}}$ & $7,00^{\mathrm{b}}$ & $142,76^{\mathrm{b}}$ \\
N1P2 & $44,16^{\mathrm{b}}$ & $7,66^{\mathrm{b}}$ & $145,73^{\mathrm{b}}$ \\
N1P3 & $46,83^{\mathrm{b}}$ & $7,83^{\mathrm{b}}$ & $161,43^{\mathrm{a}}$ \\
N1P4 & $53,33^{\mathrm{a}}$ & $8,33^{\mathrm{a}}$ & $162,83^{\mathrm{a}}$ \\
N2P1 & $49,33^{\mathrm{b}}$ & $8,50^{\mathrm{a}}$ & $151,20^{\mathrm{a}}$ \\
N2P2 & $52,66^{\mathrm{a}}$ & $8,33^{\mathrm{a}}$ & $154,20^{\mathrm{a}}$ \\
N2P3 & $63,00^{\mathrm{a}}$ & $8,33^{\mathrm{a}}$ & $163,53^{\mathrm{a}}$ \\
& $54,70^{\mathrm{a}}$ & $8,33^{\mathrm{a}}$ & $169,00^{\mathrm{a}}$ \\
\hline
\end{tabular}

Ket: Superskrip yang berbeda pada lajur yang sama menunjukkan perbedaan yang nyata $(\mathrm{P}<0,05)$.

pada lingkungan70\% naungan untuk memperoleh hasil yang sama belum membutuhkan pemupukan nitrogen.

\section{Tinggi tanaman}

Hasil uji lanjut Tukey Test menunjukkan bahwa perlakuan naungan $70 \%$ yang berinteraksi dengan level pupuk nitrogen menghasilkan tinggi tanaman nyata lebih tinggi $(\mathrm{P}<0,05)$ dibanding dengan interaksi perlakuan tanpa naungan dengan level pemupukan nitrogen N1P1 dan N1P2 masing-masing 142,76 dan $145,73 \mathrm{~cm}$, tetapi tidak berbeda nyata $(\mathrm{P}>0,05)$ dengan interaksi N1P3 dan N1P4.

Hasil panjang daun, jumlah daun dan tinggi tanaman menunjukkan bahwa untuk mencapai panjang daun yang maksimal pada kondisi lingkungan 70\% naungan hanya dibutuhkan dosis pupuk nitrogen $200 \mathrm{~kg}$ urea/ha, sedangkan pada lingkungan tanpa naungan membutuhkan $800 \mathrm{~kg}$ urea/ha, demikian juga yang dibutuhkan untuk jumlah daun. Selanjutnya tinggi tanaman maksimal dicapai pada level pemupukan $400 \mathrm{~kg}$ urea/ha pada perlakuan $0 \%$ naungan.

Data hasil penelitian menunjukkan bahwa interaksi perlakuan level pupuk nitrogen dengan naungan $70 \%$ menghasilkan panjang daun, jumlah daun dan tinggi tanaman terbaik. Meningkatnya panjang daun, jumlah daun dan tinggi tanaman pada lingkungan ternaung menunjukan respons adapatasi morfologis 
tanaman terhadap kekurangan cahaya (Ericksen and Whitney, 1981) sebagai upaya mencukupi jumlah cahaya yang tertangkap untuk proses fotosintesis (Wong and Wilson, 1980; Sirait, 2008). Tanaman yang ternaungi jumlah cahaya yang masuk akan berkurang, hal ini mengakibatkan proses fotosintesis tidak berjalan optimal dimana pembentukan organ tanaman juga terhambat seperti daun dan stolon. Tetapi tanaman yang ternaungi luas daunnya akan lebih lebar dibandingkan yang tidak ternaungi karena tanaman yang ternaungi akan memperluas permukaan daun agar mendapatkan cahaya yang optimal (Salibury dan Ross, 1995). Tekanan cahaya bisa menimbulkan respons fisiologis terutama dalam aktivitas fotosintesis maupun respon morfologis seperti berubahnya ukuran daun dan tinggi tanaman. Selain itu tinggi tanaman akan lebih cepat naik pada tempat yang teduh atau ternaungi (Moelyohadi et al., 1999).

Dari aspek penggunaan unsur hara oleh tanaman pada lingkungan ternaung kebutuhan nitrogen lebih sedikit dibandingkan pada lingkungan tanpa naungan.Hal ini disebabkan pada kondisi lingkungan ternaung terjadi dekomposisi bahan organik lebih efektif sehingga tersedia unsur nitrogen lebih banyak (Wilson and Wild, 1991). Nitrogen (N) berfungsi untuk merangsang pertumbuhan tanaman secara keseluruhan, terutama batang tanaman, mempercepat pertumbuhan tanaman, menjadikan daun tanaman menjadi lebih hijau dan segar serta banyak mengandung butir-butir hijau daun yang penting dalam proses fotosintesis (Sirait et al., 2005). Selain itu nitrogen mempunyai fungsi dapat menambah kandungan protein dalam tanaman (Suwarto, 2013).

\section{KESIMPULAN}

Berdasarkan hasil penelitian ini dapat disimpulkan bahwa :

1. Naungan berkontribusi positif dalam penyediaan unsur hara nitrogen untuk kebutuhan tanaman rumput P.purpureum cv. Mott.

2. Pada lingkungan tanpa naungan kebutuhan pupuk nitrogen lebih banyak untuk menghasilkan panjang daun, jumlah daun dan tinggi tanaman dibandingkan pada kondisi ternaung.

\section{DAFTAR PUSTAKA}

Abdullah, L. 2012. Meracik peluang bisnis inovatif pada komoditi tanaman dan hijauan pakan. Jurnal Pastura Vol. 12 (1): 1-7

Anis, S.D., D.A. Kaligis, S.P. Pangemanan. 2015. Integration of cattle and coronivia gras pasture underneat mature coconuts in 
North Sulawesi, Indonesia. J. Livestock Research for Reveral Development. Vol. 27. Paper No. 142.

Bona, D. and F.A. Monteiro. 2010. The development and production of leaf and tillers by Marundu Palisadegrass fertilized with nitrogen and sulphur. Tropical Grassland 44: 192-201.

Ericksen, F.I. and Whitney. 1981. Effect of light intensity on south of some Tropical forages species. 1 . Introshin of light intensity and nitrogen fentilize on fix forages strases, Agron. J. 73 : 427-433.

Finindi, A., S. Yuhaini dan A. Wahyu. 2005. Pertumbuhan dan Produktivitas Tanaman Sorgum (Sorghum bicolor L) Moench dan Sorgum sudanense (Piper stafp) yang Mendapatkan Kombinasi Pemupukan N,P,K dan Ca. Prosiding Seminar Nasional Peternakan dan Veteriner, 12 - 13 September di Bogor, Buku 2: 872 -885 .

Gomez, A.A. and A.A. Gomez. 1995. Prosedur Statistik untuk Penelitian Pertanian. (Edisi II). Penerbit Universitas Indonesia.

Moelyohadi, Y., Y. Koesmaryono, H. Darmasetiawan dan D. Sopandie. 1999. Pengaruh naungan terhadap intersepsi dan efisiensi penggunaan radiasi surya pada tanaman padi gogo. Jurnal Agromet. 14(1-2): 5970

Sajimin, I., P. Kompiang, Supriyati dan N. P. Suratmini. 2001. Penggunaan biofertilizer untuk penigkatan produktifitas hijauan pakan rumput gajah (Pennisetum purpureum cv Afrika) pada lahan marjinal di Subang Jawa Barat. Media Peternakan, 24 (2): 46 - 50.

Sirait, J. 2008. Luas daun, kandungan klorofil dan laju pertumbuhan rumput pada naungan dan pemupukan yang berbeda. Jurnal Ilmu Ternak dan Veteriner 13 (2): 109-116

Sirait, J., N. D. Purwantari dan K. Simanihuruk. 2005. Produksi dan serapan nitrogen rumput pada naungan dan pemupukan yang berbeda. Jurnal Ilmu Ternak dan Veteriner, 10 (3): 175 - 181.

Suwarto, 2013. Penambahan klorofil, luas daun spesifik, dan efisien penggunaan cahaya ubi kayu pada system tumpang sari dalam jagung. Bul. Agrohorti 1 (1): 135-139

Urribari, L., A. Ferrer and A. Collina. 2005. Leaf protein from ammonia treasted dwarf elephant grass (Pennisetum purpureum Cchum cv. Mott). Journal of Applied Biochemistry and Biotechnology. Humana Press Inc. Vol. 112, No. 1-3:721-730.

Wilson, J.R. and D. M. W. Wild, 1991. Improvement of nitrogen nutrition and grass growth under shading. Aciar Proceedings. 32.

Wong, C.C. and J.R. Wilson, J.R. 1980. Effects of shading on the growth and nitrogen content of green panic and siratro in pure and mixed swards defoliated at two frequencies. Australian Journal of Agricultural Research, 31: 269-285 